Nikoleta Zubic**

Zoran Sušanj**

Danijela Sokolic ${ }^{* * *}$
JEL klasifikacija: A200, L260 Izvorni znanstveni rad

https://doi.org/10.32910/ep.72.5.5

\title{
EFEKTI EDUKACIJE O PODUZETNIŠTVU NA PODUZETNIČKU SAMOEFIKASNOST, POŽELJNOST I NAMJERE STUDENATA
}

U nastojanjima poticanja gospodarskog razvoja te smanjenja nezaposlenosti i suzbijanja siromaštva sve se više prepoznaje uloga poduzetništva. Ističu se njegove brojne prednosti te se sve češće raspravlja o potrebnim poduzetničkim kompetencijama i njihovom razvoju. Glavni cilj ovog istraživanja bio je ispitati efekte edukacije o poduzetništvu na poželjnost poduzetništva, poduzetničku samoefikasnost i poduzetničke namjere studenata. U istraživanju je sudjelovalo 48 ispitanika (eksperimentalna i kontrolna skupina), a mjerenje je provedeno prije i nakon edukacije o poduzetništvu. Rezultati pokazuju da polaznici nakon edukacije značajno bolje procjenjuju svoje poduzetničke vještine i sposobnosti, međutim, na skali poželjnosti poduzetništva ostvaruju niže rezultate u odnosu na prvo mjerenje. U istraživanju su ispitivane razlike sobzirom na spol te je utvrđeno da u oba mjerenja studenti u odnosu na studentice ostvaruju statistički značajno više rezultate na svim korištenim skalama. Uspoređujući studente/ice ekonomskih i neekonomskih usmjerenja utvrđeno je kako studentilice ekonomskih usmjerenja ostvaruju više rezultate na jednom aspektu poduzetničkog potencijala (poduzetnička

" N.Zubić, dipl. oec., mag. psych., voditeljica Ureda za karijere Sveučilišnog savjetovališnog centra, Sveučilište u Rijeci (e-mail: nikoleta.zubic@uniri.hr).

** Z. Sušanj, dr. sc., redoviti profesor, Sveučilište u Rijeci, Filozofski fakultet, Odsjek za psihologiju (e-mail: zsusanj@ffri.hr).

*** D. Sokolić, dr. sc., izvanredna profesorica, Sveučilište u Rijeci, Ekonomski fakultet (e-mail: danijela.sokolic@efri.hr). Rad je primljen u uredništvo 27.02.2019. godine, a prihvaćen je za objavu 14.09.2020. godine. 
N. ZUBIĆ, Z. SUŠANJ, D. SOKOLIĆ: Efekti edukacije o poduzetništvu na poduzetničku samoefikasnost, poželjnost.. EKONOMSKI PREGLED, 72 (5) 750-773 (2021)

svjesnost) te skali poželjnosti poduzetništva, skali poduzetničkih namjera $i$ skali stupnja razvijenosti poduzetničkih znanja, vještina $i$ sposobnosti.

Ključne riječi: edukacija o poduzetništvu, poduzetnički potencijal, poduzetnička samoefikasnost, poželjnost poduzetništva, poduzetničke namjere

\section{UVOD}

Nakon 2008. godine, kada se čitava Europa suočava s najvećom gospodarskom krizom u posljednjih pedeset godina (Europska komisija, 2013), kontinuirano se nastoje osmisliti temelji za održavanje konkurentnosti te pametan i održiv rast i razvoj. Kao potencijalna društvena panacea, poduzetništvo sve češće postaje predmetom interesa i znanstvenika i praktičara (Anderson i Jack, 2008; Henry, Hill i Leitch, 2007). Sam pojam poduzetništva proizlazi iz francuske riječi »entreprende« što znači poduzeti, odnosno pokrenuti se ili činiti da se stvari događaju (Kirby, 2004; Miljković Krečar, 2010), a među brojnim definicijama ističe se ona Europske komisije (2003), prema kojoj poduzetništvo predstavlja »način razmišljanja i proces kreiranja i razvijanja ekonomskih aktivnosti stapanjem spremnosti na preuzimanje rizika, kreativnosti i/ili inovativnosti s razumnim upravljanjem, unutar nove ili postojeće organizacije«. Već je iz same definicije jasno vidljivo kako je poduzetništvo kompleksan, višerazinski fenomen čije istraživanje zahtijeva interdisciplinaran pristup koji uključuje različita područja poput psihologije, sociologije, ekonomije i drugih disciplina. U počecima istraživanja pažnja se uglavnom usmjeravala na osobne karakteristike kojima je moguće predvidjeti sudjelovanje i uspjeh u poduzetničkim aktivnostima. Tako su od šezdesetih godina prošlog stoljeća identificirani brojni motivi i osobine ličnosti poduzetnika koje se povezuju s uspjehom u poduzetništvu, poput potrebe za postignućem (McClelland, 1965), savjesnosti, otvorenosti, ekstraverzije (Zhao, Seibert i Lumpkin, 2010), inovativnosti, samoefikasnosti, tolerancije na stres (Rauch i Frese, 2007), sklonosti preuzimanju rizika (Zhao i Seibert, 2006), kreativnosti, intuicije i divergentnog mišljenja (Hirisch, Lagan - Fox i Grant, 2007). Uz kreativnost, kao snažne prediktore poduzetničkih aktivnosti Ahmetoglu i Chamorro-Premuzic (2010) ističu poduzetničku svjesnost, oportunizam i potrebu za napretkom. Nadalje, nekoliko autora naglašava kako motivi određuju dvije kategorije poduzetnika - tzv. »poduzetnike iz nužde«, koji su uglavnom usmjereni na »preživljavanje«, odnosno alternativne načine ostvarivanja prihoda u uvjetima kada nemaju izbora (npr. prinudno samozapošljavanje zbog gubitka zaposlenja) te »poduzetnike iz prilike«, koji postaju poduzetnici neovisno o drugim atraktivnim opcijama zaposlenja (Carsrud i Brännback, 2011; Reynolds, Gartner, Greene, Cox i Carter, 2002; Singer, 2006). Valja napomenuti kako u zemljama s prosječnim i nižim prihodima poput Hrvat- 
ske, većina poduzeća nastaje »iz nužde«, dok zemlje s višim prihodima karakterizira poduzetništvo potaknuto prilikama.

$\mathrm{S}$ obzirom da konsenzus o univerzalnom poduzetničkom profilu nije postignut, devedesetih se godina prošlog stoljeća pažnja sve više usmjerava na kognicije poduzetnika. Ovdje najvažniju ulogu ima namjera, koja predstavlja snažan i dosljedan prediktor planiranog ponašanja (Ajzen, 1991). Poduzetnička se namjera definira kao nečija želja za samoodređivanjem vlastitog posla ili započinjanjem vlastitog biznisa (Krueger, Reilly i Carsrud, 2000), a dva najčešće korištena teorijska okvira kojima se nastoje utvrditi njezini elementi su Ajzenova teorija planiranog ponašanja (engl. Theory of planned behaviour - TPB; Ajzen, 1991) i Model poduzetničkog događaja (engl. Model of the Entrepreneurial Event - EEM; Shapero i Sokol, 1982). Prema TPB namjeru određuju stavovi prema ponašanju, subjektivne norme i percipirana ponašajna kontrola, dok prema EEM poduzetnička namjera ovisi o percipiranoj poželjnosti, sklonosti ka djelovanju i percipiranoj izvedivosti. Brojni autori ističu kompatibilnost oba modela (Krueger i sur. 2000; Liñán i Chen, 2006; Peterman i Kennedy, 2003). Naime, percipirana se poželjnost u EEM smatra rezultatom društvenog i kulturalnog utjecaja, stoga obuhvaća Ajzenov koncept stava prema ponašanju te subjektivnu normu, dok percipirana izvedivost odgovara percipiranoj ponašajnoj kontroli. U oba modela vanjski čimbenici na namjeru utječu neizravno, putem percepcije poželjnosti i izvedivosti. S obzirom da uključuju percipiranu sposobnost izvođenja ponašanja, valja napomenuti kako su percipirana ponašajna kontrola u Ajzenovom modelu, te percipirana izvedivost u Modelu poduzetničkog događaja vrlo slične pojmu samoefikasnosti (Liñán, 2004). Poduzetnička samoefikasnost u brojnim je istraživanjima najznačajniji pojedinačni prediktor poduzetničkih namjera i poduzetničkog ponašanja, ali i značajan prediktor kasnijeg uspjeha poduzeća (Miljković Krečar, 2012; Otuya, Kibas, Gichira i Martin, 2013). Uključivanjem osobnih karakteristika te usporedbom, ali i integracijom oba modela, Jakopec, Miljković Krečar i Sušanj (2013) utvrdili su kako poduzetnički potencijal, kao kompozit osobnih karakteristika (poduzetničke svjesnosti, potrebe za napretkom, oportunizma i poduzetničke kreativnosti), poduzetnička samoefikasnost i poželjnost poduzetništva objašnjavaju čak 69\% varijance poduzetničke namjere studenata, što dodatno potvrđuje navedene teorijske okvire. Mjere svih navedenih konstrukata korištene su u ovom istraživanju čiji je temeljni cilj ispitivanje učinaka sudjelovanja u edukaciji o poduzetništvu na poželjnost poduzetništva, poduzetničku samoefikasnost i poduzetničke namjere studenata.

Što se demografskih varijabli tiče, rezultati istraživanja pokazuju da najvišu poduzetničku aktivnost imaju osobe u dobi od 25. do 34. godine života (Reynolds i sur., 2002). Stoga se upravo studenti nerijetko smatraju idealnim uzorkom za istraživanje poduzetničkih namjera (Sesen, 2013). Nadalje, vrlo se često primjećuje niža poduzetnička aktivnost žena u odnosu na muškarce (Do Paco, Ferreira, Raposo, 
Rodrigues i Dinis, 2013; Karimi, Biemans, Lans, Chizari, Mulder i Mahdei, 2013; Sanchez-Cañizares i Fuentes-Garcia, 2013). U skladu s očekivanjima, isto vrijedi i za poduzetničke namjere (Chen, Greene i Crick 1998; Ertuna i Gurel, 2011; Gupta, Turban i Wasti, 2009; Liñán, Roomi i Santos, 2010; Verheul, Thurik, Grilo, i Van der Zwan, 2012; Zhao, Seibert i Hills, 2005).

Budući da se poduzetnička aktivnost ne događa u vakuumu, na percepcije koje pojedinci mogu imati u vezi poželjnosti i izvedivosti poduzetničke aktivnosti može, izravno i neizravno, utjecati i nacionalna, regionalna, profesionalna i/ili korporativna kultura (Fayolle i Liñán, 2014). Osim različitog vrednovanja određenih motivacijskih faktora poput autonomije, zarade, uspostavljanja novog posla, doživljaja neuspjeha i sl., poduzetnička aktivnost može ovisiti i o slici koju poduzetnik ima u pojedinom društvu, odnosno o imidžu poduzetnika (León, Gorgievski i Lukes, 2008; Kirby, 2004). Naime, s jedne se strane poduzetnici percipiraju ključnima za rast i razvoj gospodarstva, dok se s druge strane nerijetko smatraju izrabljivačima, egoističnim i pohlepnim osobama koje zanima samo profit i povećanje kapitala. Stav prema poduzetništvu i imidž poduzetnika mogu se razlikovati od zemlje do zemlje, a na njih mogu utjecati brojni okolinski čimbenici poput političke infrastrukture, zakonodavnih okvira, financijske podrške, stabilnosti tržišta, kvalitete obrazovanja, marketinga, obiteljske podrške i sl. Osim toga, u kontekstu razvoja poduzetničkog duha, sve više istraživača ističe važnost atmosfere na sveučilištu (Bergmann, Hundt i Sternberg, 2016; Guerrero, Urbano i Fayolle, 2016; Guerrero, Urbano, Fayolle, Klofsten i Mian, 2016; Lüthje i Franke, 2004). U skladu s navedenim, u ovom su se istraživanju, osim učinaka edukacije o poduzetništvu, provjeravale i razlike u poduzetničkim namjerama i nekim njihovim ranije opisanim prediktorima s obzirom na spol te studijsko usmjerenje sudionika. Prema dosadašnjim istraživanjima viši rezultati očekivani su kod studenata u odnosu na studentice te kod onih koji studiraju ekonomska u odnosu na neekonomska usmjerenja.

\section{EDUKACIJA O PODUZETNIŠTVU}

Istraživanja suprotstavljaju dva pristupa u određivanju podloge za razvoj uspješnog poduzetnika: prema jednom, poduzetničke su odrednice urođene, dok se prema drugom poduzetničke vještine stječu kroz iskustvo i edukaciju (Parker, 2009; Turik, 2015). Tako se prema prvom pristupu kao temeljni čimbenik poduzetničkog uspjeha ističe »poduzetnički gen «, odnosno urođena sklonost poduzetništvu, dok drugi pristup pretpostavlja da se poduzetništvo, ili barem neki njegovi elementi, mogu naučiti. Pod pretpostavkom da se na sklonost i uspjeh u poduzetništvu može utjecati, a obzirom da europske, u odnosu na američke zemlje, 
prilično zaostaju u razvoju poduzetništva, provodi se niz inicijativa i intervencija usmjerenih na poticanje poduzetničkog ponašanja. Temeljem strateškog plana »Poduzetništvo 2020 « nastoji se potaknuti razvoj malih i srednjih poduzeća provođenjem poduzetničkih edukacija i treninga, uklanjanjem administrativnih barijera te razvojem i njegovanjem poduzetničke kulture u svim europskim zemljama (Europska komisija, 2013). Ministarstvo poduzetništva i obrta Republike Hrvatske također na različite načine nastoji unaprijediti konkurentnost subjekata malog gospodarstva. S tim u skladu, strategijom razvoja poduzetništva u RH za razdoblje od 2013. do 2020. godine nastoji se ostvariti pet strateških ciljeva: poboljšanje ekonomske uspješnosti, poboljšan pristup financiranju, promocija poduzetništva, poboljšanje poduzetničkih vještina te poboljšanje poslovnog okruženja (Ministarstvo poduzetništva i obrta, 2013). Poduzetničko obrazovanje namijenjeno razvoju poduzetničkih kompetencija (znanja, vještina, sposobnosti i osobnih kvaliteta) na svim edukacijskim razinama ima sve značajniju ulogu. Sadržaj i metode podučavanja često se razlikuju s obzirom na percepciju koncepta poduzetništva, ciljeve edukacije (od razvoja osobnih vještina pa do stvaranja inovativnih poduhvata), populaciju koja je uključena i razinu edukacije. Stoga poduzetnički programi mogu varirati u rasponu od vrlo kratkih tečajeva koji se fokusiraju na razvoj poduzetničkih znanja i vještina vezanih uz započinjanje posla (tzv. »start up«), do potpunih akademskih programa (kolegija) koji pružaju šire konceptualno i teorijsko razumijevanje teme. Valja također napomenuti kako su dosad poduzetnički programi većinom bili dostupni isključivo studentima ekonomskih usmjerenja, dok je posljednjih godina uočen trend specifično dizajniranih programa za studente neekonomskih usmjerenja, poput umjetničkih ili inženjerskih.

Prema socijalno kognitivnoj teoriji, osobno iskustvo, verbalna persuazija, vikarijsko iskustvo uz procjenu tjelesnih indikatora, odnosno fizioloških i afektivnih stanja, temeljni su izvori samoefikasnosti (Bandura, 1997; prema Miljković Krečar, 2012), ranije opisanog koncepta koji je iznimno važan za angažiranje i uspjeh u poduzetničkoj aktivnosti. U skladu s tim, Peterman i Kennedy (2003) navode kako najefikasniji edukativni programi namijenjeni razvoju poduzetničkih vještina na području SAD-a uključuju interaktivno učenje, učenje temeljeno na iskustvu, modele uloga te stvaranje poslovnih mreža i mreža u zajednici. Miljković Krečar (2010) također ističe kako se poduzetništvo i poduzetnost najbolje uče kroz osobno iskustvo ili učenjem po modelu. Takav pristup može uključivati različite aktivnosti poput razvoja poslovnog plana, studentskih poslovnih start-up-ova, studija slučaja, intervjua sa stvarnim poduzetnicima te računalnih simulacija koje snažno odražavaju konstruktivistički model podučavanja. S obzirom da je poslovni plan jedan od prvih koraka poslovnog poduhvata te je jedan od najvažnijih komunikacijskih alata poduzetnika (White, Hertz i D’Souza, 2011), njegova izrada često spada među najvažnije komponente edukacija o poduzetništvu (Arasti, Falavarjani i Imanipour, 2012; Honig, 2004; Kirby, 2004). Priprema poslovnog plana omogu- 
ćuje studentima integraciju i primjenu poduzetničkih znanja i vještina poput generiranja kreativnih ideja, identifikacije poslovnih prilika, marketinga, organizacijskog ponašanja, računovodstva, financija i sl. Takvim učenjem konstruktivističke prirode studenti mogu vlastitom aktivnošću naučiti predviđati, razvijati kontakte koji su im potrebni da bi ostvarili projekt, identificirati vlastite slabosti te razumjeti međuovisnost njihove odluke (Carrier, 2007). U skladu s politikom Europske unije i Hrvatska je prepoznala važnost razvoja poduzetničkih vještina te je u razdoblju od 2001. do 2010. godine za poduzetničko obrazovanje utrošeno čak 4,9 milijuna eura (Kraljić, 2012). S obzirom na porast ponude, ali i uložena financijska sredstva, nameće se pitanje učinkovitosti obrazovnih programa.

Dosadašnja istraživanja uglavnom ukazuju na pozitivnu povezanost pohađanja edukacije i poduzetničkih namjera i ponašanja sudionika (Dutta, Li i Merenda, 2010; Fayolle i Gailly, 2004; Gielnik, Uy, Funken i Bischoff, 2017; Lindberg, Bohman, Hulten i Wilson, 2017; Lee, Chang i Lim, 2005; Lüthje i Franke, 2002; Nabi, Liñán, Fayolle, Krueger i Walmsley, 2017; Liu, Lin, Zhao i Zhao, 2019; Noel, 2001; Sušanj, Jakopec i Miljković Krečar, 2015; Zhao i sur., 2005). Usmjeravajući se na specifične prediktore poduzetničke namjere, Chen i suradnici (1998) su utvrdili da studenti poduzetništva imaju statistički značajno višu razinu samoefikasnosti nego studenti ostalih usmjerenja. Slične rezultate dobiva Noel (2001) koji zaključuje da studenti završne godine studija poduzetništva imaju snažnije poduzetničke namjere te viši osjećaj samoefikasnosti u odnosu na studente menadžmenta ili studente drugih usmjerenja. Da je obrazovanje povezano s poduzetničkom samoefikasnošću ili ponašajnom kontrolom potvrđuju i drugi autori (Fayolle i Gailly, 2004; Wilson, Kickul i Marlino, 2007; Zhao i sur., 2005). Preciznije, Shah, Amjed i Jaboob (2020) potvrdili su moderatorsku ulogu edukacije o poduzetništvu u jačanju odnosa između poduzetničke samoefikasnosti i poduzetničke namjere.

Efikasnost edukacije o poduzetništvu su Peterman i Kennedy (2003) ispitivali u terminima percepcije poželjnosti i izvedivosti učenika srednjih škola da započnu vlastiti posao. Učenici koji su sudjelovali u edukaciji u trajanju od pet mjeseci ostvarili su više rezultate na obje varijable od onih koji nisu sudjelovali. Nadalje, osim što potvrđuju pozitivnu povezanost pohađanja studija ekonomskih usmjerenja na poduzetničku samoefikasnost, poželjnost i poduzetničke namjere, uspoređujući rezultate studenata ekonomskih u odnosu na one neekonomskih usmjerenja, Sušanj i suradnici (2015) su utvrdili da je efekt medijacije poduzetničke samoefikasnosti i poželjnosti poduzetništva na namjere kod studenata ekonomskih usmjerenja snažniji.

Uz nedovoljan broj provedenih istraživanja učinaka edukacije o poduzetništvu na poduzetničke namjere, nerijetko se ističe i potreba za korištenjem rigoroznijih metoda testiranja unaprijed postavljenih hipoteza (Duval-Couetil, 2013; Fayolle i Klandt, 2006; Lorz, Mueller i Volery, 2013; Nabi i sur., 2017; Peterman i Kennedy, 
2003). Primjerice, pregledom literature Lorz i suradnici (2013) zaključuju kako čak 27 od 39 (62\%) studija koje ispituju poduzetničke namjere ne koristi nacrt ponovljenih mjerenja, a od tih 27 , čak 18 ne uključuje kontrolnu skupinu, što otežava provođenje meta-analiza.

S obzirom da je jedan od ciljeva vlade RH poticanje poduzetništva u visokom obrazovanju, pojedine regije ulažu sredstva u programe za podučavanje poduzetništva kod studenata. U skladu s tim, Ekonomski fakultet Sveučilišta u Rijeci u suradnji s Primorsko-goranskom županijom organizirao je i proveo edukaciju o poduzetništvu za studente riječkog Sveučilišta pod nazivom „BEST“ (engl. Business Education for Students). U svrhu što bolje pripreme studenata završnih godina studija za svijet poduzetništva, program je obuhvaćao dvije cjeline: teorijsku (temeljna teorijska znanja o poduzetništvu, zakonskoj regulativi, marketingu) i praktičnu (vježbe, izrada i priprema poslovnog plana, izrada marketinških strategija, poslovno komuniciranje i prodajne vještine). Temeljni je cilj programa bio razvoj poslovnih vještina koje će studentima olakšati snalaženje i upravljanje u poslovnome svijetu. Program je trajao 39 sati te je uključivao 13 radionica s odabranim temama u okviru 5 modula (Poduzetništvo, Poslovna i razvojna politika, Prezentacijske i komunikacijske vještine, poslovno komuniciranje i prodajne vještine, Marketing te Poduzetnička infrastruktura, zakonodavni okvir i društveno odgovorno poslovanje). Osim pohađanja nastave, koju su uz profesore u većem dijelu izvodili poduzetnici iz prakse, studenti su trebali izraditi poslovni plan, što je bilo osmišljeno kao grupni zadatak. Nakon odslušanih predavanja te izrade i prezentacije poslovnih planova, timu koji je izradio najbolji poslovni plan dodijeljena je simbolična novčana nagrada.

Provođenje navedenog programa pružilo je priliku za ispitivanje efekata edukacije na poželjnost poduzetništva (PP), poduzetničku samoefikasnost (PSE), poduzetničke namjere (PN) i samoprocjenu stupnja razvijenosti znanja, vještina i sposobnosti (SRZVIS) potrebnih kod pojedinih aspekata poduzetništva. Također je ispitan utjecaj demografskih varijabli (spol i studijsko usmjerenje) na navedene varijable (PP, PSE, PN, SRZVIS), kao i odnos samoprocjena korisnosti svakog pojedinog modula i stupnja razvijenosti vještina i sposobnosti potrebnih za pojedine aspekte poduzetništva koje su obuhvaćene tim modulom.

Pretpostavljeno je da će studenti nakon sudjelovanja u edukaciji o poduzetništvu (eksperimentalna skupina) ostvariti statistički značajno više rezultate na skalama PP, PSE, PN i SRZVIS, u odnosu na prvo mjerenje (prije početka edukacijskog programa) (H1a). Nadalje, rezultati kontrolne skupine studenata (ekvivalentni parovi) u drugom mjerenju (nakon završetka edukacijskog programa) neće se razlikovati u odnosu na prvo mjerenje (prije početka edukacijskog programa) na navedenim skalama (H1b). Također se očekuje da se rezultat polaznika edukacije na istim skalama neće statistički značajno razlikovati u odnosu na kontrolnu sku- 
pinu ispitanika pri prvom mjerenju (prije početka edukacijskog programa) (H2a), no polaznici edukacije će ostvariti statistički značajno više rezultate u odnosu na kontrolnu skupinu ispitanika u drugom mjerenju (nakon završetka edukacijskog programa) (H2b).

Očekuje se da će studenti ostvariti statistički značajno više rezultate na korištenim skalama (PP, PSE, PN i SRZVIS) u odnosu na studentice u oba mjerenja (H3a). Nadalje, studenti/ice ekonomskih usmjerenja ostvarit će statistički značajno više rezultate na skalama (PP, PSE, PN i SRZVIS) u odnosu na studente/ice neekonomskih usmjerenja (H3b). Konačno, očekuje se da će procjena korisnosti i zadovoljstva studenata radionicama/predavanjima karakterističnima za pojedini modul biti pozitivno povezana sa samoprocjenom stupnja stečenih znanja, vještina i sposobnosti potrebnih kod pojedinih aspekata poduzetništva koje su obuhvaćene tim modulom (H4).

\section{METODA}

\subsection{Ispitanici}

U istraživanju je sudjelovalo ukupno 48 studenata završnih godina preddiplomskih i diplomskih studija Sveučilišta u Rijeci, raspona dobi od 21 do 28 godina. Od toga je 16 studenata (7 studenata i 9 studentica) dobrovoljno sudjelovalo u edukaciji o poduzetništvu, dok je 32 studenata (14 studenata i 18 studentica) predstavljalo kontrolnu skupinu koja nije sudjelovala u edukaciji. Za svakog polaznika edukacije odabrani su ekvivalentni parovi (po dva studenta za svakog polaznika) koji su bili izjednačeni po spolu, dobi, fakultetu kojeg pohađaju, godini studija i prosjeku ocjena. Kategorija ekonomskog usmjerenja obuhvaća studente Ekonomskog fakulteta različitih smjerova poput Opće ekonomije, Međunarodnog poslovanja, Menadžmenta, Financija i bankarstva (ukupno 24 studenta), dok kategoriju neekonomskog usmjerenja predstavljaju studenti Filozofskog fakulteta, Odjela za biotehnologiju, Pomorskog fakulteta, Tehničkog fakulteta i Informatike (ukupno 24 studenta).

\subsection{Mjerni instrumenti}

Mjera poduzetničkih tendencija i sposobnosti (META L61; Ahmetoglu i Chamorro-Premuzic, 2010) namijenjena je ispitivanju osobnih karakteristika 
poduzetnika. Sastoji se od 61 čestice kojima se mjere 4 različita aspekta poduzetničke osobnosti: poduzetnička svjesnost (11 čestica), oportunizam (18 čestica), poduzetnička kreativnost (12 čestica) i potreba za napretkom (20 čestica). Ispitanici na skali Likertovog tipa procjenjuju u kojem se stupnju slažu s određenom tvrdnjom, pri čemu 1 označava »Uopće se ne slažem《, a 5 »U potpunosti se slažem«. Kompozitni rezultat dobiva se izračunom aritmetičke sredine procjena svih tvrdnji i označava mjeru poduzetničkog potencijala, pri čemu viši rezultat označava viši poduzetnički potencijal. Osim potvrde ranije opisanih teorijskih modela - Ajzenove teorije planiranog ponašanja (engl. Theory of planned behaviour - TPB; Ajzen, 1991) i Modela poduzetničkog događaja (engl. Model of the Entrepreneurial Event - EEM; Shapero i Sokol, 1982), Jakopec i suradnici (2013) u svom su istraživanju, korištenjem mjernih instrumenata prilagođenih našoj populaciji, na uzorku od 315 studenata ekonomskih usmjerenja riječkog, osječkog i zagrebačkog Sveučilišta utvrdili i zadovoljavajuće koeficijente pouzdanosti pojedinih mjera koje su navedene u nastavku. Cronbach alpha koeficijent za mjeru cjelokupnog poduzetničkog potencijala iznosio je 0,96 , za dimenziju poduzetničke svjesnosti 0,92 , za oportunizam 0,95, za poduzetničku kreativnost 0,97, a za potrebu za napretkom 0,93.

Za mjerenje opće poduzetničke samoefikasnosti korištena je Skala poduzetničke samoefikasnosti (Liñán i Chen, 2006). Ispitanici na skali Likertovog tipa procjenjuju u kojem se stupnju slažu s određenom tvrdnjom, pri čemu 1 označava »Uopće se ne slažem«, a 5 »U potpunosti se slažem«. Skala se sastoji od 6 čestica. Kompozitni rezultat dobiva se izračunom aritmetičke sredine procjena svih tvrdnji, pri čemu viši rezultat ukazuje na veću poduzetničku samoefikasnost. Jakopec i suradnici (2013) utvrdili su koeficijent unutarnje konzistencije koji je iznosio 0,79.

Skala poželjnosti poduzetništva (Liñán i Chen, 2006) namijenjena je mjerenju osobne želje za započinjanje poslovanja. Ispitanici na skali Likertovog tipa procjenjuju u kojem se stupnju slažu s određenom tvrdnjom pri čemu 1 označava »Uopće se ne slažem«, a 5 »U potpunosti se slažem«. Skala se sastoji od 5 čestica. Kompozitni rezultat dobiva se izračunom aritmetičke sredine procjena svih tvrdnji pri čemu viši rezultat ukazuje na veću poželjnost poduzetništva. Cronbach alpha koeficijent iznosio je 0,86 (Jakopec i sur., 2013).

Za samoprocjenu poduzetničkih namjera korišten je Upitnik poduzetničkih namjera (Liñán i Chen, 2006) koji se sastoji od 7 čestica. Prva čestica je kategorijalnog tipa te se od ispitanika traži da odgovore jesu li ikad ozbiljno razmišljali o tome da postanu poduzetnici/e (DA - NE). Za preostalih 6 čestica ispitanici na skali Likertovog tipa procjenjuju stupanj u kojemu se slažu s pojedinom tvrdnjom pri čemu 1 označava »Uopće se ne slažem«, a $5 » U$ potpunosti se slažem«. Kompozitni rezultat dobiva se izračunom aritmetičke sredine procjena svih tvrdnji, a viši rezultat ukazuje na više poduzetničke namjere. U istraživanju kojeg su proveli Jakopec i suradnici (2013) Cronbach alpha koeficijent iznosio je 0,90. 
Za samoprocjenu znanja konstruirana je Skala stupnja razvijenosti znanja, vještina $i$ sposobnosti potrebnih kod pojedinih aspekata poduzetništva koja je obuhvaćala 21 česticu. Čestice na skali prilagođene su sadržaju različitih modula programa edukacije, a ispitanici ih procjenjuju na skali od 1 (Uopće nemam razvijene sposobnosti i vještine) do 5 (Imam u potpunosti razvijene vještine i sposobnosti).

Osim navedenih skala, u upitniku je korišten i niz pitanja s ciljem dobivanja deskriptivnih podataka poput spola, dobi, fakulteta, odnosno studijskog usmjerenja kojeg studenti pohađaju te godini studija i prosjeku ocjena. Uz to, postavljena su i pitanja o načinima zarađivanja i preuzimanju inicijative radi poboljšanja obrazovanja ili boljitka zajednice.

$\mathrm{S}$ ciljem ispitivanja korisnosti i zadovoljstva sudionika programa, u istraživanju su korišteni i Obrasci za evaluaciju predavanja/radionice. Svaki obrazac sastojao se od 7 tvrdnji, koje su ispitanici procjenjivali na skali od 1 (Najmanje se odnosi na mene) do 5 (U potpunosti se odnosi na mene), te nekoliko pitanja otvorenog tipa poput »Što vam je bilo najkorisnije što ste naučili, saznali ili doživjeli

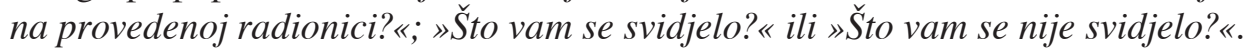

\subsection{Postupak istraživanja}

Ispitanici koji su odlučili pohađati edukaciju o poduzetništvu zamoljeni su da ispune upitnik neposredno prije prvog predavanja/radionice. $U$ istom tjednu kada započinje program, upitnik su ispunili i ekvivalentni parovi (po dva studenta za svakog polaznika) koji su izjednačeni po spolu, dobi, fakultetu kojeg pohađaju, godini studija i prosjeku ocjena. U uputi je svim sudionicima istraživanja navedeno kako se tvrdnje odnose na njihove stavove, sklonosti i ponašanja te se upitnikom želi provjeriti način gledanja na budućnost i osobni profesionalni razvoj studenata. Također je istaknuto kako se nije potrebno previše zadržavati na pojedinim tvrdnjama, već je poželjno rješavanje po »prvom osjećaju« te kako je istraživanjem u potpunosti osigurana povjerljivost podataka, a dobiveni rezultati koristit će se isključivo u znanstveno - istraživačke svrhe. Isti postupak ponovljen je u posljednjem tjednu provođenja programa. Uz to, nakon svakog predavanja/radionice polaznici programa zamoljeni su da ispune kratak obrazac za procjenu korisnosti i zadovoljstva radionicom/predavanjem. 


\section{REZULTATI I RASPRAVA}

Cjelokupna statistička analiza podataka provedena je uz pomoć računalnog programa Statistical Package for Social Sciences, SPSS verzija 20.0. Izračunate su pouzdanosti za svaku od skala te deskriptivni podaci dobiveni u prvom i drugom mjerenju na cjelokupnom uzorku koji su prikazani u Tablici 1.

\section{Tablica 1.}

ARITMETIČKA SREDINA (M), STANDARDNA DEVIJACIJA (SD) I POUZDANOST TIPA CRONBACH ALFA (A) KORIŠTENIH SKALA

\begin{tabular}{|l|c|c|c|c|c|c|c|}
\hline \multirow{2}{*}{ Mjera } & \multirow{2}{*}{$\begin{array}{c}\text { Broj } \\
\text { čestica }\end{array}$} & \multicolumn{3}{|c|}{ Prvo mjerenje } & \multicolumn{3}{|c|}{ Drugo mjerenje } \\
\cline { 4 - 8 } $\begin{array}{l}\text { Mjera poduzetničkih tendencija i } \\
\text { sposobnosti }\end{array}$ & 61 & 3,51 & 0,48 & 0,88 & 3,47 & 0,46 & 0,82 \\
\hline Poduzetnička svjesnost & 11 & 3,28 & 0,61 & 0,85 & 3,28 & 0,57 & 0,84 \\
\hline Oportunizam & 18 & 3,36 & 0,57 & 0,88 & 3,30 & 0,60 & 0,9 \\
\hline Poduzetnička kreativnost & 12 & 3,36 & 0,48 & 0,75 & 3,31 & 0,51 & 0,78 \\
\hline Želja za napretkom & 20 & 3,90 & 0,52 & 0,86 & 3,88 & 0,53 & 0,88 \\
\hline Poduzetnička samoefikasnost (PSE) & 6 & 3,55 & 0,65 & 0,73 & 3,57 & 0,76 & 0,83 \\
\hline Poželjnost poduzetništva (PP) & 5 & 3,74 & 0,98 & 0,91 & 3,54 & 0,99 & 0,86 \\
\hline Poduzetničke namjere (PN) & 6 & 3,37 & 1,12 & 0,94 & 3,27 & 1,17 & 0,95 \\
\hline $\begin{array}{l}\text { Skala stupnja razvijenosti znanja, } \\
\text { vještina i sposobnosti (SRZVIS) }\end{array}$ & 21 & 3,25 & 0,69 & 0,95 & 3,34 & 0,79 & 0,96 \\
\hline
\end{tabular}

Izvor: Autori

Nadalje, izračunati su deskriptivni podaci kontrolne i eksperimentalne skupine za svako mjerenje koji su prikazani u Tablici 2. 
N. ZUBIĆ, Z. SUŠANJ, D. SOKOLIĆ: Efekti edukacije o poduzetništvu na poduzetničku samoefikasnost, poželjnost.. EKONOMSKI PREGLED, 72 (5) 750-773 (2021)

Tablica 2.

ARITMETIČKE SREDINE (M) I STANDARDNE DEVIJACIJE (SD) DVIJU SKUPINA PRI PRVOM I DRUGOM MJERENJU

\begin{tabular}{|l|c|c|c|c|c|c|c|c|}
\hline & \multicolumn{4}{|c|}{ Prvo mjerenje } & \multicolumn{4}{c|}{ Drugo mjerenje } \\
\hline \multirow{2}{*}{ Mjera } & \multicolumn{2}{|c|}{$\begin{array}{c}\text { Eksperimentalna } \\
\text { skupina }\end{array}$} & $\begin{array}{c}\text { Kontrolna } \\
\text { skupina }\end{array}$ & \multicolumn{2}{c|}{$\begin{array}{c}\text { Eksperimentalna } \\
\text { skupina }\end{array}$} & \multicolumn{2}{|c|}{$\begin{array}{c}\text { Kontrolna } \\
\text { skupina }\end{array}$} \\
\cline { 2 - 10 } & M & SD & M & SD & M & SD & M & SD \\
\hline $\begin{array}{l}\text { Mjera } \\
\text { poduzetničkih } \\
\text { tendencija i } \\
\text { sposobnosti }\end{array}$ & 3,62 & 0,48 & 3,47 & 0,46 & 3,65 & 0,46 & 3,41 & 0,43 \\
\hline $\begin{array}{l}\text { Poduzetnička } \\
\text { svjesnost }\end{array}$ & 3,34 & 0,53 & 3,25 & 0,66 & 3,40 & 0,51 & 3,22 & 0,57 \\
\hline Oportunizam & 3,55 & 0,63 & 3,26 & 0,51 & 3,46 & 0,62 & 3,22 & 0,56 \\
\hline $\begin{array}{l}\text { Poduzetnička } \\
\text { kreativnost }\end{array}$ & 3,25 & 0,51 & 3,42 & 0,45 & 3,37 & 0,58 & 3,28 & 0,46 \\
\hline $\begin{array}{l}\text { Želja za } \\
\text { napretkom }\end{array}$ & 4,07 & 0,45 & 3,82 & 0,52 & 4,13 & 0,51 & 3,76 & 0,50 \\
\hline $\begin{array}{l}\text { Poduzetnička } \\
\text { samoefikasnost } \\
\text { (PSE) }\end{array}$ & 3,50 & 0,70 & 3,57 & 0,64 & 3,67 & 1,10 & 3,52 & 0,74 \\
\hline $\begin{array}{l}\text { Poželjnost } \\
\text { poduzetništva } \\
\text { (PP) }\end{array}$ & 4,05 & 0,74 & 3,58 & 1,06 & 3,65 & 0,88 & 3,49 & 1,03 \\
\hline $\begin{array}{l}\text { Poduzetničke } \\
\text { namjere (PN) }\end{array}$ & 3,65 & 1,10 & 3,22 & 1,11 & 3,61 & 1,16 & 3,11 & 1,14 \\
\hline $\begin{array}{l}\text { Skala stupnja } \\
\text { razvijenosti } \\
\text { znanja, vještina } \\
\text { i sposobnosti } \\
\text { (SRZVIS) }\end{array}$ & 3,21 & 0,58 & 3,27 & 0,75 & 3,75 & 0,49 & 3,14 & 0,82 \\
\hline
\end{tabular}

Izvor: Autori 


\subsection{Efekti edukacije o poduzetništvu}

Kako bi se odgovorilo na temeljno pitanje ovog istraživanja, odnosno ispitalo postoji li efekt edukacije o poduzetništvu na poduzetničku samoefikasnost, poželjnost i namjere studenata, provedena je mješovita MANOVA s ponovljenim mjerenjima (2x2). Radi povećanja metodološke strogosti istraživanja te smanjenja vjerojatnosti precjenjivanja efekata korišten je nacrt s ponovljenim mjerenjima, a u istraživanje su uključene i eksperimentalna i kontrolna skupina ispitanika.

S obzirom na utvrđenu statistički značajnu interakciju između vremena mjerenja i grupne pripadnosti na Skali stupnja razvijenosti znanja, vještina $i$ sposobnosti potrebnih kod pojedinih aspekata poduzetništva utvrđen je pozitivan efekt pohađanja edukacije $\left(\mathrm{F}_{1.46}=26,36 ; \mathrm{p}<0,01\right)$. Također je utvrđen glavni efekt vremena mjerenja $\left(\mathrm{F}_{1,46}=10,12 ; \mathrm{p}=0,003\right)$, dok efekt grupne pripadnosti nije potvrđen. Rezultati su prikazani na Slici 1.

Slika 1.

\section{RAZLIKA IZMEĐU GRUPA KROZ VRIJEME NA SKALI STUPNJA RAZVIJENOSTI ZNANJA, VJEŠTINA I SPOSOBNOSTI (SRZVIS)}

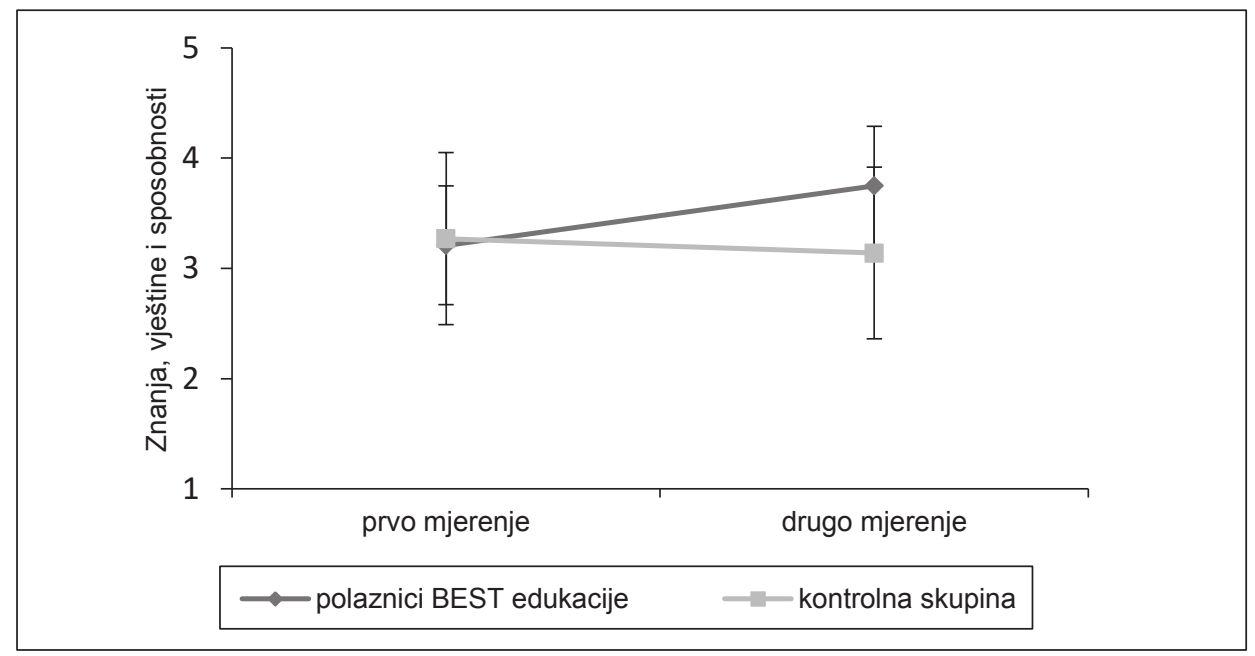

Izvor: Autori 
T-testom je utvrđena statistički značajna razlika među rezultatima koje su polaznici edukacije ostvarili u drugom, u odnosu na prvo mjerenje $(\mathrm{t}=6,86$; $\mathrm{df}=15$; $\mathrm{p}<0,01)$. Polaznici edukacije ostvarili su statistički značajno više rezultate u drugom $(\mathrm{M}=3,75 ; \mathrm{SD}=0,49)$, u odnosu na prvo mjerenje $(\mathrm{M}=3,21 ; \mathrm{SD}=0,58)$. Statistički značajna razlika u rezultatima kontrolne skupine s obzirom na vrijeme mjerenja nije utvrđena. Na Slici 1. vidljivo je kako su rezultati kontrolne i eksperimentalne skupine u prvom mjerenju vrlo slični, no u drugom je mjerenju utvrđena statistički značajna razlika među rezultatima $(t=2,72$; $d f=46 ; p<0,05)$. Eksperimentalna skupina je nakon pohađanja edukativnog programa svoje vještine i sposobnosti procjenjivala višima $(\mathrm{M}=3,75 ; \mathrm{SD}=0,49)$ u odnosu na kontrolnu $(\mathrm{M}=3,14 ; \mathrm{SD}=0,82)$, što dodatno potvrđuje efekt edukacije.

Unatoč višoj razini samoprocjene vlastitih kompetencija, očekivana pozitivna promjena u rezultatima na Skali poduzetničke samoefikasnosti, Skali poželjnosti poduzetništva i Skali poduzetničkih namjera na uzorku studenata koji su pohađali edukaciju nije potvrđena. Zanimljivo, na Skali poželjnosti poduzetništva ostvareni su rezultati suprotni od očekivanih. Analizom rezultata postignutih na Skali poželjnosti poduzetništva utvrđen je glavni efekt vremena mjerenja $\left(\mathrm{F}_{1,46}=8,71\right.$, $\mathrm{p}<0,01$ ), dok glavni efekt pripadnosti grupi kao ni statistički značajna interakcija između vremena mjerenja i pripadnosti grupi nisu utvrđene. T-testom je potvrđena statistički značajna razlika u rezultatima koje je eksperimentalna skupina postigla pri prvom i drugom mjerenju ( $\mathrm{t}=2,39$; $\mathrm{df}=15 ; \mathrm{p}<0,05)$. U drugom mjerenju polaznici edukacije ostvaruju statistički značajno niže rezultate na Skali poželjnosti poduzetništva $(\mathrm{M}=3,65 ; \mathrm{SD}=0,88)$, u odnosu na prvo mjerenje $(\mathrm{M}=4,05$; $\mathrm{SD}=0,74)$. Kontrolna skupina nije ostvarila statistički značajno različite rezultate u drugom u odnosu na prvo mjerenje. S obzirom da je potvrđena jedna od četiri komponente, H1a je tek djelomično potvrđena.

U literaturi postoji manji broj novijih istraživanja koji ukazuju na smanjenje poduzetničkih namjera studenata nakon sudjelovanja u edukacijama o poduzetništvu (Oosterbeek, van Praag i Ijseelsetin, 2010; Rodrigues, Dinis, do Paco, Ferreira i Raposo, 2012; Von Graevenitz, Harho i Weber, 2010). Zanimljivo, unatoč smanjenju razine poduzetničkih namjera autori poput Rodriguesa i suradnika (2012) te Von Graevenitza i suradnika (2010) nalaze interpretiraju u terminima pozitivnih ishoda edukacija. Kao argument za to ističu smanjenje zastupljenosti neutralnih odgovora te povećanje sigurnosti u vlastiti izbor. U tom smislu, program oblikuje ideje o tome što znači biti poduzetnik i stvara kritičnu svjesnost, elemente koje autori poput Raea (2010) ističu kao glavne ciljeve edukacije o poduzetništvu. Oosterbeek i suradnici (2010) ističu da je razlog nižih poduzetničkih namjera to što su sudionici izgubili pretjerani optimizam o poduzetništvu i odbacili ideju da postanu poduzetnici nakon završetka programa. U ovom je istraživanju moguće da su sudionici edukacije, usvajanjem relevantnih informacija o tome što poduzetniš- 
tvo zapravo jest, dobili realističnu sliku o mogućim preprekama, koja je doprinijela smanjenju poželjnosti odabira poduzetničke karijere. Nadalje, s obzirom da su ustanovili kako poduzetnički poduhvat nije jednostavan proces, moguće je da je do izražaja došao strah od neuspjeha, konstrukt koji nije posebno ispitivan u ovom istraživanju. Rezultati GEM istraživanja primjerice sugeriraju da je ovaj inhibitor poduzetničkog ponašanja često prisutan kod poduzetnika u nastajanju u Republici Hrvatskoj (Singer, Šarlija, Pfeifer i Oberman Peterka, 2012). Uz to, prema Institutu za društvena istraživanja (2007) strah od neuspjeha može biti jedan od razloga zbog kojega su hrvatski učenici, unatoč otvorenosti prema novim iskustvima, manje skloni primijeniti nove načine rješavanja problema. Prilikom interpretacije dobivenih rezultata svakako u obzir treba uzeti i trajanje edukacije. Moguće je da je 39 nastavnih sati ipak nedovoljno za postizanje pozitivnih promjena u percepciji poduzetništva kao karijerne opcije.

U skladu s očekivanjima, kontrolna skupina (ekvivalentni parovi) nije ostvarila statistički značajno različite rezultate na Skali poželjnosti poduzetništva, Skali poduzetničke samoefikasnosti, Skali poduzetničkih namjera te Skali stupnja razvijenosti znanja, vještina i sposobnosti u drugom u odnosu na prvo mjerenje, stoga je H1b u potpunosti potvrđena. S obzirom da se rezultat između kontrolne i eksperimentalne skupine u prvom mjerenju nije statistički značajno razlikovao ni na jednoj od navedenih skala, u potpunosti je potvrđena i H2a. Iako je očekivano kako će se rezultati među skupinama razlikovati u drugom mjerenju, statistički značajna razlika dobivena je jedino na Skali stupnja razvijenosti znanja, vještina $i$ sposobnosti, pri čemu su sudionici edukacije ostvarili statistički značajno više rezultate u odnosu na kontrolnu skupinu. Rezultati među skupinama na ostalim ispitivanim skalama nisu se statistički značajno razlikovali u drugom mjerenju, stoga je H2b tek djelomično potvrđena.

\subsection{Razlike s obzirom na spol}

Mješovitom MANOVOM utvrđene su statistički značajne spolne razlike $\mathrm{u}$ poduzetničkom potencijalu $\left(\mathrm{F}_{1,46}=12,21 ; \mathrm{p}<0,01\right)$. Studenti ostvaruju više rezultate od studentica u oba mjerenja. Isto je potvrđeno na skalama pojedinačnih aspekata poduzetničkog potencijala, odnosno na Skali poduzetničke svjesnosti $\left(\mathrm{F}_{1,46}=21,72 ; \mathrm{p}<0,01\right)$, oportunizma $\left(\mathrm{F}_{1,46}=8,64, \mathrm{p}<0,01\right)$, poduzetničke kreativnosti $\left(\mathrm{F}_{1,46}=5,18 ; \mathrm{p}<0,05\right)$ i želje za napretkom $\left(\mathrm{F}_{1,46}=6,09 ; \mathrm{p}<0,05\right)$. Na Skali poduzetničke samoefikasnosti $\left(\mathrm{F}_{1,46}=8,39 ; \mathrm{p}<0,01\right)$, Skali poželjnosti poduzetništva $\left(\mathrm{F}_{1,46}=8,39 ; \mathrm{p}<0,01\right)$, Skali poduzetničkih namjera $\left(\mathrm{F}_{1,46}=24,45 ; \mathrm{p}<0,01\right)$, Skali stupnja razvijenosti znanja, vještina i sposobnosti također je utvrđen glavni 
efekt spola $\left(\mathrm{F}_{1,46}=13,52 ; \mathrm{p}<0,01\right)$, pri čemu studenti ostvaruju više rezultate $\mathrm{u}$ odnosu na studentice. Time je u potpunosti potvrđena H3a.

Da se muškarci češće angažiraju u poduzetničkim aktivnostima ukazuju rezultati brojnih istraživanja (Do Paco i sur., 2013; Karimi i sur., 2013; SanchezCañizares i Fuentes-Garcia, 2013), a da žene imaju manje povjerenja u svoje poduzetničke vještine potvrđeno je na uzorku koji je obuhvaćao ispitanike iz čak 17 zemalja (Koellinger, Minniti i Schade, 2013). Niža razina poduzetničke samoefikasnosti kod žena potvrđena je i u novijim istraživanjima (Vamvaka, Stoforos, Palaskas i Botsaris, 2020).

Nadalje, muškarci često procjenjuju da imaju viši stupanj inicijative, kreativnosti, samopouzdanja, optimizma, tolerancije za potencijalni neuspjeh, dok se žene procjenjuju kao marljivije, samodiscipliniranije radnice spremne na ulaganje više truda kako bi postigle rezultate te s višim strahom od rizika. Kolić-Vehovec u svom istraživanju provedenom 1988. godine na uzorku hrvatskih studenata ukazuje kako studentice karakterizira viši strah od neuspjeha u odnosu na studente. Kasnije potvrđuje kako studentice osim većeg straha od neuspjeha karakterizira i viši strah od odgovornosti nakon uspjeha te se češće percipiraju nekompetentnijima od studenata (Kolić-Vehovec, 1993). Brojni autori ističu kako su za objašnjenje navedenih razlika vrlo važni rodni stereotipi i socijalno prihvaćanje (Do Paco i sur., 2013; Pablo-Martí, García-Tabuenca i Crespo-Espert, 2014; Sweida i Reichard, 2013). Nadalje, Liñán i suradnici (2010) ističu kako spolne razlike u poduzetničkoj aktivnosti ovise o kulturalnom aspektu, odnosno nacionalnim vrijednostima. Naime, utvrdili su kako kulturalni kontekst pojedine zemlje snažnije utječe na percepcije i poduzetničke namjere kod studentica u odnosu na studente.

\subsection{Razlike s obzirom na studijsko usmjerenje (ekonomsko/neekonomsko)}

Glavni efekt studijskog usmjerenja ostvaren je na Skali poduzetničke svjesnosti $(\mathrm{F} 1,46=4,69, \mathrm{p}<0,05)$, Skali poželjnosti poduzetništva $\left(\mathrm{F}_{1,46}=7,08 ; \mathrm{p}<0,05\right)$, Skali poduzetničkih namjera $\left(\mathrm{F}_{1,46}=9,10 ; \mathrm{p}<0,01\right)$ te Skali stupnja razvijenosti stečenih znanja, vještina $i$ sposobnosti potrebnih kod pojedinih aspekata poduzetništva $\left(\mathrm{F}_{1,46}=5,73 ; \mathrm{p}<0,05\right)$, pri čemu studenti ekonomskog usmjerenja ostvaruju više rezultate u odnosu na studente ostalih usmjerenja u oba mjerenja. Na Skali poželjnosti poduzetništva utvrđen je i glavni efekt vremena mjerenja $\left(\mathrm{F}_{1,46}=6,12 ; \mathrm{p}<0,05\right)$. Na uzorku studenata ekonomskih usmjerenja t-testom je utvrđena statistički značajna razlika u rezultatima s obzirom na vrijeme mjerenja $(\mathrm{t}=2,26 ; \mathrm{df}=23 ; \mathrm{p}<0,05)$, pri čemu oni u drugom mjerenju ostvaruju niži rezultat $(\mathrm{M}=3,81 ; \mathrm{SD}=0,80) \mathrm{u}$ odnosu na prvo mjerenje $(\mathrm{M}=4,14 ; \mathrm{SD}=0,64)$. Glavni 
efekt vremena mjerenja nije utvrđen na ostalim skalama, kao ni statistički značajne interakcije grupe i vremena mjerenja. S tim u skladu H3b je djelomično potvrđena. S obzirom na višu razinu poželjnosti poduzetništva, poduzetničkih namjera i poduzetničke svjesnosti, rezultati su u skladu s ranijim istraživanjima koja potvrđuju pozitivan efekt edukacije na sveučilišnoj razini (pohađanje studija ekonomskog usmjerenja) (Sušanj i sur., 2015). Ipak, potvrđuju i činjenicu da se u Republici Hrvatskoj o poduzetništvu govori uglavnom na ekonomskim fakultetima, dok je na ostalim studijskim usmjerenjima ova tema manje zastupljena. Zanimljiv je nalaz da se poželjnost poduzetništva nakon edukacije statistički značajno smanjila samo na uzorku studenata ekonomskih usmjerenja. Dobiveni rezultat može sugerirati kako su studenti ekonomskih usmjerenja bolje razumjeli prezentirani sadržaj, s obzirom da posjeduju višu razinu prethodnih znanja o ovom području. Drugim riječima, moguće je da je upravo bolje razumijevanje tematike dovelo do smanjenja poželjnosti poduzetništva kao karijerne opcije.

Važno je također napomenuti da, s obzirom na procjene zadovoljstva i korisnosti pojedinih predavanja (s prosječnom ocjenom u rasponu od 3,50 do 4,00 ocjenjeno je 27,3\% predavanja/radionica, dok je s ocjenom većom od 4,00 ocijenjeno $72,7 \%$ provedenih predavanja ili radionica), možemo zaključiti kako su studenti uglavnom bili zadovoljni predavanjima/radionicama. Ipak, očekivana statistički značajna pozitivna povezanost zadovoljstva sa stupnjem stečenih znanja, vještina i sposobnosti karakterističnih za pojedini modul, nije potvrđena, pa je H4 u potpunosti odbačena.

S obzirom da su studenti pozitivno procijenili edukaciju te svoje kompetencije procijenili višima nakon nje, dok su poduzetničke namjere i samoefikasnost ostale nepromijenjene, a poželjnost poduzetništva se smanjila, potrebno je razmotriti i mogućnost da su ispitanici na prve dvije navedene skale davali socijalno poželjne odgovore.

\section{ZAKLJUČAK}

Prije donošenja zaključaka valja istaknuti ograničenja istraživanja. Osim što se temelji na subjektivnim procjenama te postoji mogućnost davanja socijalno poželjnih odgovora, istraživanje karakterizira relativno mali broj ispitanika. Sam broj sudionika edukacije moguće ukazuje da poduzetništvo nije dovoljno atraktivna karijerna opcija među studentima riječkog Sveučilišta.

Rezultati istraživanja, unatoč višoj razini samoprocjene vlastitih kompetencija, ukazuju da sudjelovanje u edukaciji uglavnom nije dovelo do očekivanih promjena. Već je ranije istaknuto kako za angažiranje u poduzetničkim aktivno- 
stima samo posjedovanje odgovarajućih kompetencija nije dovoljno. Naime, osim razvoja znanja, vještina i sposobnosti vrlo je važno da studenti razviju pozitivne stavove prema poduzetništvu, povjerenje u vlastite sposobnosti, nauče prihvatiti neuspjeh te učinkovito upravljaju emocijama. Rezultati također upućuju na niz neodgovorenih pitanja vezanih uz pravovremenost poduzetničkog obrazovanja, učinkovitost metoda, trajanje i prilagođenost programa različitim skupinama koje su manje sklone poduzetničkoj aktivnosti poput osoba ženskog spola ili pak studenata neekonomskih usmjerenja. U daljnjim istraživanjima poželjno je istražiti i eventualne kulturalne specifičnosti.

\section{LITERATURA}

1. Ahmetoglu, G., i Chamorro-Premuzic, T. (2010). Measure of entrepreneurial tendencies and abilities. Unpublished Measure (available on request).

2. Ajzen, I. (1991). The theory of planned behavior. Organizational behavior and human decision processes, 50, 179-211.

3. Anderson, A.R., i Jack, S. L. (2008). Role typologies for enterprising education: The professional artisan? Journal of small business and enterprise development, 15(2), 259-273.

4. Arasti, Z., Falavarjani, M.K. i Imanipour, N. (2012). A study of teaching methods in entrepreneurship education for graduate students. Higher education studies, 2(1), 2-10.

5. Bergmann, H., Hundt, C. i Sternberg, R. (2016). What makes student entrepreneurs? On the relevance (and irrelevance) of the university and the regional context for student start-ups. Small Business Economics, 47, 53-76.

6. Carrier, C. (2007). Strategies for teaching entrepreneurship: what else beyond lectures, case studies and business plans? U: A. Fayolle (Ur.) Handbook of research in entrepreneurship education: A general perspective (str. 143-159). Northampton: Edward Elgar Publishing, Inc.

7. Carsrud., A., i Brännback, M. (2011). Entrepreneurial motivations: What do we still need to know? Journal of small business management, 49 (1), 9-26.

8. Chen, G.C., Greene, P.G., i Crick, A. (1998). Does entrepreneurial selfefficacy distinguish entrepreneurs from managers? Journal of business venturing, 13, 295-317.

9. Do Paco, A., Ferreira, J.M., Raposo, M., Rodrigues, R. G., i Dinis, A. (2013). Entrepreneurial intentions: is education enough? International entrepreneurship and management journal, 1-19. 
10. Dutta, D. K., Li, J., i Merenda, M. (2010). Fostering entrepreneurship: Impact of specialization and diversity in education. International entrepreneurship and management, 7, 163-179.

11. Duval-Couetil, N. (2013). Assessing the impact of entrepreneurship education programs: Challenges and approaches. Journal of small business management, 51(3), 394-409.

12. Ertuna, Z. I., i Gurel, E. (2011). The moderating role of higher education on entrepreneurship. Education plus training, 53(5), 387-402.

13. Europska komisija (2003). Green Paper Entrepreneurship in Europe, Brussels. Dostupno na http://ec.europa.eu/invest-in-research/pdf/download_en/ entrepreneurship_europe.pdf

14. Europska komisija (2013). Entrepreneurship 2020 Action Plan: Reigniting the entrepreneurial spirit in Europe. Communication from the Commission to the European Parliament, The Council, The European economic and social committee and the Committee of the regions. Dostupno na http://eur-lex.europa.eu/legal-content/EN/TXT/PDF/?uri=CELEX:52012DC0795ifrom=EN

15. Fayolle, A., i Gailly, B. (2004). 'Using the theory of planned behaviour to assess entrepreneurship teaching programs: a first experimentation', paper presented at IntEnt2004 conference, Naples, 5-7 Jul.

16. Fayolle, A., i Klandt, H. (2006). Issues and newness in the field of entrepreneurship education: New lenses for new practical and academic questions. U: A., Fayolle i H. Klandt (Ur.) International enterpreneurship education (str.117). Northampton: Edward Elgar Publishing, Inc.

17. Fayolle, A., i Liñán, F. (2014). The future of research on entrepreneurial intentions. Journal of Business Research, 663-666.

18. Gielnik, M. M., Uy, M. A., Funken, R., i Bischoff, K. M. (2017). Boosting and sustaining passion: A long-term perspective on the effects of entrepreneurship training. Journal of business venturing, 32(3), 334-353.

19. Guerrero, M., Urbano, D. i Fayolle, A. (2016). Entrepreneurial activity and regional competitiveness: evidence from European entrepreneurial universities. The journal of tehnology transfer, 41, 105-131.

20. Guerrero, M., Urbano, D., Fayolle, A., Klofsten, M. i Mian, S. (2016). Entrepreneurial universities: emerging models in the new social and economic landscape. Small Business Economics, 47, 551-563.

21. Gupta, V.K., Turban, D.B., i Wasti, S. A. (2009). The role of gender stereotypes in perceptions of entrepreneurs and intentions to become an entrepreneur. Entrepreneurship theory and practice, 397-417. 
22. Henry, C., Hill, F. M., i Leitch, C. M. (2007). Evaluating entrepreneurship education and training: Implications for programme design. U: A. Fayolle (Ur.) Handbook of research in entrepreneurship education: A general perspective (str. 248-260). Northampton: Edward Elgar Publishing, Inc.

23. Hisrich, R., Langan-Fox, J., i Grant, S. (2007). Entrepreneurship research and practice: A call to action for psychology, American psychologist, 62(6), 575-589.

24. Honig, B. (2004). Entrepreneurship education: Toward a model of contingency based business planning. Academy of management learning and education, 3(3), 258-273.

25. Institut za društvena istraživanja (2007). Ključne kompetencije „Učiti kako učiti“ $i$ „Poduzetništvo“ u Osnovnom školstvu Republike Hrvatske. Zagreb: Centar za istraživanje i razvoj obrazovanja.

26. Jakopec, A., Miljković Krečar, I., i Sušanj, Z. (2013). Predictors of entrepreneurial intentions of students of economics. Studia psychologica, 55(4), 289-297.

27. Karimi, S., Biemans, H.J.A., Lans, T., Chizari, M., Mulder, M., i Mahdei, K. N. (2013). Understanding role models and gender influences on entrepreneurial intentions among college students. Procedia - social and behavioral sciences, 93, 204-214.

28. Kirby, D.A. (2004). Entrepreneurship education: Can business schools meet the challenge? Education plus training, 46, 510-519.

29. Koellinger, P., Minniti, M., i Schade, C. (2013). Gender differences in entrepreneurial propensity. Oxford bulletin of economics and statistics, 75, 213-235.

30. Kolić, S. (1988). Strah od uspjeha i strah od neuspjeha - provjera konstrukta. Magistarski rad. Zagreb: Filozofski fakultet.

31. Kolić-Vehovec, S. (1993). Strah od posljedica uspjeha i strah od neuspjeha u odnosu na motiv postignuća i percipiranu kompetentnost. Godišnjak Zavoda za psihologiju, 2, 115-121.

32. Kraljić, T. (2012). Važnost učenja za poduzetništvo u uvjetima velikih strukturnih promjena hrvatskog gospodarstva i poslovanja na jedinstvenom tržištu Europske unije. Učenje za poduzetništvo, 2(1), 235-244.

33. Krueger, N.F. (2003). The cognitive psychology of entrepreneurship. U: Z.J. Acs i D. B. Audretsch (Ur.) Handbook of Entrepreneurship Research: An interdisciplinary survey and introduction. (str. 105-140). London: Kluwer academic publishers.

34. Krueger, N.F., Reilly, A. L., i Carsrud, A.L. (2000). Competing models of entrepreneurial intentions. Journal of business venturing, 15, 411-432. 
35. Lee, S.M., Chang, D., i Lim, S. (2005). Impact of entrepreneurship education: A comparative study of the U.S. and Korea. International entrepreneurship and management journal, 1, 27-43.

36. León, J. A. M., Gorgievski, M., i Lukes, M. (2008). Teaching psychology of entrepreneurship: Research and education. Madrid: Universidad Nacional de Educación a Distancia.

37. Liñán, F. (2004). Intention-based models of entrepreneurship education. Small business, 3, 11-35.

38. Liñán, F., i Chen,Y. (2006). Testing the entrepreneurial intention model on a two-country sample. Document de Treball Universitat Autňnoma de Barcelona: Departament d'Economia de l'Empresa.

39. Liñán, F., Roomi, M. A., i Santos, F.J. (2010). A cognitive attempt to understanding female entrepreneurial potential: The role of social norms and culture. Departament d'Economia de l'Empresa, 1-45.

40. Lindberg, E, Bohman, H. Hulten, P. i Wilson, T. (2017). Enhancing students' entrepreneurial mindset: a Swedish experience. Education plus training, 59(7/8), 768-779.

41. Liu, X., Lin, C., Zhao, G. i Zhao, D. (2019). Research on the effects of entrepreneurial education and entrepreneurial self- efficacy on college students' entrepreneurial intention. Frontiers in Psychology, 10, 1-9.

42. Lorz, M., Mueller, S., i Volery, T. (2013). Entrepreneurship education: A systematic review of the methods in impact studies. Journal of enterprising culture, 2l(2), 123-151.

43. Lüthje, C., i Franke, N. (2004). Entrepreneurial intentions of business students: A benchmarking study. International journal of innovation and technology management, 1(3). 269-288.

44. McClelland, D.C. (1965). Achievement and enterpreneurship: A longitudinal study. Journal of personality and social psychology, 1(4), 389-392.

45. Miljković Krečar, I. (2010). Razvoj poduzetničkih kompetencija u sustavu cjeloživotnog obrazovanja. Napredak, 151(3-4), 417-432.

46. Miljković Krečar, I. (2012). Predviđanje poduzetničkog ponašanja u okviru Bandurine teorije samoefikasnosti. Doktorska disertacija. Zagreb: Filozofski fakultet u Zagrebu.

47. Ministarstvo poduzetništva i obrta (2013). Strategija razvoja poduzetništva u Republici Hrvatskoj 2013.-2020. Zagreb.

48. Nabi, G., Liñán F., Fayolle, A., Krueger, N. i Walmsley, A. (2017). The impact of entrepreneurship education in higher education: A systematic review and research agenda. Academy of management learning i education, 16(2), 277-299. 
49. Noel, T.W. (2002). Effects of entrepreneurial education on intent to open a business: An exploratory study. Journal of entrepreneurship education, 3-13.

50. Oosterbeek, H., van Praag, M., i Ijseelsetin, A. (2010). The impact of entrepreneurship education on entrepreneurship skills and motivation. European economic review, 54, 442-454.

51. Otuya, R., Kibas, P., Gichira, R., i Martin, W. (2013). Entrepreneurship education: Influencing students' enterpreneurial intentions. International journal of innovative research and studies, 2(4), 132-148.

52. Pablo-Martí, F., García-Tabuenca, A., i Crespo-Espert, J. L. (2014). Do gender related differences exist in Spanish entrepreneurial activities? International journal of gender and entrepreneurship, 6(2), 200-214.

53. Parker, S.C. (2009). The Economics of Entrepreneurship. Cambridge: Cambridge University Press.

54. Peterman, N.E., i Kennedy, J. (2003). Enterprise education: Influencing students' perceptions of entrepreneurship. Entrepreneurship theory and practice, 129-144.

55. Rae, D. (2010). Universities and enterprise education: responding to the challenges of the new era. Journal of small business and enterprise development, 17(4), 591-606.

56. Rauch, A., i Frese, M. (2007). Let's put the person back into entrepreneurship research: A meta-analysis on the relationship between business owners' personality traits, business creation, and success. European journal of work and organizational psychology, 16(4), 353-385.

57. Reynolds, P. D., Gartner, W. B., Greene, P. G., Cox, L. W., i Carter, N. M. (2002). The entrepreneur next door: Characteristics of individuals starting companies in America: An executive summary of the panel study of entrepreneurial dynamics. Dostupno na http://papers.ssrn.com/sol3/papers. cfm?abstract_id=1262320

58. Rodrigues, R.G., Dinis, A., do Paco, A., Ferreira, J., i Raposo M. (2012). The effect of an entrepreneurial training programme on entrepreneurial traits and intention of secondary students. Entrepreneurship-born, made and educated, 77-92.

59. Sanchez-Cañizares, S.M., i Fuentes-Garcia, F. (2013). Gender and entrepreneurship: Analysis of a young university population. Regional and sectorial economic studies, 13(1), 65-78.

60. Sesen, H. (2013). Personality or environment? A comprehensive study on the entrepreneurial intentions of university students. Education plus training, 55(7), 624-640. 
61. Shah, I., Amjed, S. i Jaboob, S. (2020). The moderating role of entrepreneurship education in shaping entrepreneurial intentions. Journal of Economic Structures, 9(19), 1-15.

62. Shapero, A., i Sokol, L., (1982). The social dimensions of entrepreneurship. U: C.A. Kent, D.L. Sexton, K.H. Vesper (Ur.), Encyclopedia of Entrepreneurship (str. 72-90). New York: Prentice Hall/Englewood Cliffs.

63. Singer, S. (2006). What makes Croatia an entrepreneurial country? Results of Global Entrepreneurship Monitor for Croatia. Zagreb: CEPOR - Centar za politiku razvoja.

64. Singer, S., Šarlija, N., Pfeifer, S., i Oberman Peterka S. (2012). What makes Croatia a (non)entrepreneurial country? Zagreb: CEPOR - Centar za politiku razvoja.

65. Sušanj, Z., Jakopec, A., i Krečar Miljković, I. (2015). Verifying the model of predicting entrepreneurial intention among students of business and nonbusiness orientation. Management, 20(2), 49-69.

66. Sweida, G.L., i Reichard, R. J. (2013). Gender stereotyping effects on entrepreneurial self-efficacy and high-growth entrepreneurial intention. Journal of small business and enterprise development, 20(2), 296-313.

67. Thurik, A.R., (2015). Determinants of entrepreneurship. U: D.B. Audretsch, Ch.S. Hayter and A.N. Link (Ur.), Concise Guide to Entrepreneurship, Technology and Innovation (str. 28. - 38.), Cheltenham, UK: Edward Elgar Publishing Limited.

68. Vamvaka, V., Stoforos, C., Palaskas, S. i Botsaris C. (2020). Attitude toward entrepreneurship, perceived behavioral control, and entrepreneurial intention: dimensionality, structural relationships, and gender differences. Journal of Innovation and Entrepreneurship, 9(5), 1-26.

69. Verheul., I., Thurik, R., Grilo, I., i Van der Zwan, P. (2012). Explaining preferences and actual involvement in self-employment: Gender and the entrepreneurial personality. Journal of economic psychology, 33, 325-341.

70. Von Graevenitz, G., Harho, D., i Weber, R. (2010). The effects of entrepreneurship education. Journal of economic behavior and organization, 76(1), 1-39.

71. White, R., Hertz, G., i D’Souza, R. (2011). Teaching a craft - Enhancing entrepreneurship pedagogy. Small business institute journal, 7, 1-14.

72. Wilson, F., Kickul, J., i Marlino, D. (2007). Gender, entrepreneurial self-efficacy, and entrepreneurial career intentions: Implications for entrepreneurship education. Entrepreneurship theory and practice, 387-406. 
73. Zhao, H., i Seibert, S.E. (2006). The Big Five personality dimensions and entrepreneurial status: A meta-analytical review. Journal of applied psychology, 91(2), 259-271.

74. Zhao, H., Seibert, S.E,. i Hills, G.E. (2005). The mediating role of self-efficacy in the development of entrepreneurial intentions. American psychological association, 90(6), 1265-1272.

75. Zhao, H., Seibert, S.E., i Lumpkin, G.T. (2010). The relationship of personality to entrepreneurial intentions and performance: A meta-analytic review. Journal of management, 36(2), 381-404.

\title{
EFFECTS OF ENTREPRENEURSHIP EDUCATION ON ENTREPRENEURIAL SELF-EFFICACY, DESIRABILITY OF ENTREPRENEURSHIP AND ENTREPRENEURIAL INTENTIONS OF STUDENTS
}

\author{
Summary
}

In the efforts to stimulate economic development, reduce unemployment and tackle poverty, the role of entrepreneurship is increasingly recognized. Its numerous benefits are emphasized and it is increasingly discussed about the necessary entrepreneurial competencies and their development. The aim of this study was to examine the effects of education program on entrepreneurship desirability, entrepreneurial self-efficacy and entrepreneurial intentions of students. In total 48 students participated in the study (experimental and control group). All measurements were carried out before and after the entrepreneurship education program. The results indicate that attendees significantly improve their entrepreneurial skills and abilities after their education. However, on the scale of entrepreneurial desirability they achieve lower results after the program. The gender differences were investigated and the results indicated that male students achieved statistically significant higher results on all scales used, at both measurements. By comparing students of economic and non-economic orientation, it was established that the students of economic orientation achieve higher results in one aspect of entrepreneurial potential (entrepreneurial awareness) as well as at the desirability of entrepreneurship scale, entrepreneurial intentions scale and at the development of entrepreneurial skills and abilities scale.

Key words: entrepreneurship education, entrepreneurial potential, entrepreneurial self-efficacy, desirability of entrepreneurship, entrepreneurial intentions 